\title{
Genetic variation within three populations of Phycella australis (Phil.) Ravenna from Biobío Region, Chile, evaluated using ISSR markers
}

\author{
Cristian Flores ${ }^{1}$, Catherine Delaveau ${ }^{1}$, Carolina Alvarez ${ }^{1}$, Dafne Vergara ${ }^{1}$, Carlos Baeza ${ }^{2}$, \\ Eduardo Ruiz ${ }^{2}$, and Matilde Uribe ${ }^{3 *}$
}

\begin{abstract}
Phycella australis (Phil.) Ravenna is a Chilean plant with high ornamental potential; however, the intensive extraction as a cut flower might be detrimental for the conservational state by ignoring the state of genetic variation. The objective of this investigation was to assess genetic variability within and between three populations of P. australis in the Biobío Region using inter-simple sequence repeat (ISSR) markers. The evaluated areas correspond to three locations in the province of Concepción, Biobío Region: Desembocadura (36 $48^{\prime}$ S, $73^{\circ} 10^{\prime}$ W), Santa Juana ( $36^{\circ} 58^{\prime}$ S, $72^{\circ} 58^{\prime}$ W), and Lipinhue (3700' S, $72^{\circ} 58^{\prime}$ W). Six ISSR primers were used obtaining 51 fragments, from which $72.5 \%$ were polymorphic. From the three evaluated sites Santa Juana showed a higher percentage of polymorphic loci (76.47\%). From this variability, $83 \%$ belong to within population variability and only $17 \%$ belong to variability between populations. The dendrogram generated using the unweighted pair group method with arithmetic mean (UPGMA) method, grouped Lipinhue and Santa Juana sites together, which agrees with the geographic locations. This investigation proved that $P$. australis has high genetic variability despite the exploitation for economic purposes.
\end{abstract}

Key words: Amaryllidaceae, genetic variability, molecular marker, ornamental plant.

\section{INTRODUCTION}

Chile's position in the international market for cut flowers has had an upward trend over the past $15 \mathrm{yr}$, but at the end of this period show signs of stagnation (Reyes and Barrera, 2009). However, Chile still has a great level of exportation of cut flowers to Netherland, USA, Japan, Argentina, among others; reaching close to US $\$ 4$ million annually (Reyes and Barrera, 2009). Nevertheless, still is a weak competitor in relation with the production of traditional flowers. An economic strategy to cope with this problem is to offer species such as Phycella australis (Phil.) Ravenna, a species that is now beginning to be marketed in the Biobío Region, Chile, which due that is an endemic flower would not have any competitors abroad.

The Phycella genus (Amaryllidaceae) is endemic from Chile and Argentina, includes six different species (Arroyo-Leuenberger and Dutilh, 2008) distributed along the central zone of Chile, between Coquimbo and Biobío Regions. Phycella plants are perennial, bulbous with

\footnotetext{
${ }^{1}$ Universidad de Concepción, Centro de Biotecnología, Barrio Universitario s/n, Concepción, Chile.

${ }^{2}$ Universidad de Concepción, Facultad de Ciencias Naturales y Oceanográficas, Barrio Universitario s/n, Casilla 160-C; Concepción, Chile.

${ }^{3}$ Universidad de Concepción, Facultad de Ciencias Forestales, Barrio Universitario s/n, Casilla 160-C; Concepción, Chile.

"Corresponding author (muribe@udec.cl).

Received: 26 July 2012.

Accepted: 9 January 2013.
}

flowers arranged in umbels with 2-3 flowers, red and yellowish in the base tepals (Baeza et al., 2007a), flowers are 3 to $5 \mathrm{~cm}$ in size, being $P$. australis the most austral distributed plant in the country (Baeza et al., 2007a).

Phycella australis is a species with high ornamental potential (Muñoz et al., 2011), due to their desirable characteristics as a cut flowers which includes long stem, big flowers, and bright colors. However, the massive extraction of these flowers may become a risk to the permanence of this plant in their natural environment, especially if the present level of genetic diversity is unknown, including the genetic variation rates and population structures.

There is limited genetic information about $P$. australis, however, the chromosomic number has been determined, indicating that is a species with $2 n=2 x=$ 16 chromosomes, just like P. bicolor Ruiz et Pav. (Baeza et al., 2007a; 2007b). Besides, the karyotype was also described, indicating that $P$. australis has an asymmetric karyotype with haploid form $2 \mathrm{~m}+4 \mathrm{sm}+2 \mathrm{st}$. On the other hand, Schiappacasse et al. (2005) reported different types of sexual and asexual propagation in different geophytes plants from Chile, including $P$. australis. With respect to genetic variation, no studies have been informed in this species.

As noted in field, there is an incipient commercial exploitation of the species in the Biobío Region that consists in the flower extraction from their natural habitat to be commercialized in local flower markets. The extraction or overexploitation of flowers from populations 
with low genetic diversity might cause damage in the evolutionary response of population to adapt to changes in the environment, affecting the conservational state (Lande and Shannon, 1996; Lynch, 1996). Therefore the lack of information on population genetics of $P$. australis makes necessary the generation of research that allow the development of knowledge about the current conservational state and how this can be affected by the exhaustive flower extraction for economic purposes.

In this regard, molecular markers represent a highly accurate tool for evaluating genetic diversity (Arnao et al., 2008). They allow the recognition of polymorphic regions within the genome excluding the influence of environmental effects or the developmental state of the individual (Jiménez and Collada, 2000; Semagn et al., 2006). Specifically inter simple sequence repeats (ISSR) are dominant markers that do not need previous knowledge of the DNA sequence (Lara et al., 2003). They are fast, simple to perform, and unlike random amplified polymorphic DNA (RAPDs) are more reproducible due to the longest primer sequences, and able to generate highly polymorphic patterns, being use frequently in studies involved in genetic diversity in plants (Parab and Krishnan, 2008). Works such as Fuentes et al. (2007) in Rhodophiala Presl., Lara et al. (2003) in Psychotria acuminata Benth, and Deng et al. (2006a) in Lycoris longituba Y. Xu \& G.J. Fan, among others, are examples of the use of ISSR markers, and often in conjunction with RAPDs marker to assess the genetic variation in plants.

In this scientific note, the genetic variation between and among population in the endemic plant Phycella australis in three populations of the Biobío Region was estimated using ISSR markers.

\section{MATERIALS AND METHODS}

\section{Plant material}

Thirty-six $P$. australis (Figure 1) individuals were collected randomly from three populations (12 each) located in the Biobío Region (Figure 2), leaves samples were taken. Populations were named: Desembocadura (36 $48^{\circ}$ S, 7310' W), Santa Juana (36 $58^{\circ}$ S, $72^{\circ} 58^{\prime}$ $\mathrm{W})$, and Lipinhue (37 $\left.00^{\prime} \mathrm{S}, 72^{\circ} 58^{\prime} \mathrm{W}\right)$. Samples were immediately submerged in liquid nitrogen, transported to the laboratory and saved at $-80{ }^{\circ} \mathrm{C}$ until its analysis.

\section{Total DNA extraction}

Genomic DNA was isolated from $150 \mathrm{mg}$ of powdered leaves using liquid nitrogen and used the $2 \mathrm{X}$ CTAB (cetyltrimethylammonium bromide) protocols of Doyle and Doyle (1987). The extraction buffer consisted of $2 \%$ CTAB, $2 \mathrm{M} \mathrm{NaCl}, 50 \mathrm{mM}$ EDTA, $100 \mathrm{mM}$ Tris$\mathrm{HCl} \mathrm{pH} 8.0,2 \% \mathrm{PVP}, 8 \mathrm{mM}$ ascorbic acid, and $5 \mathrm{mM}$ DIECA. The suspension was mixed, incubated at $60{ }^{\circ} \mathrm{C}$ for $45 \mathrm{~min}$, followed by chlorophorm:isoamyl alcohol (24:1) extraction and precipitation with 1.5 volume of

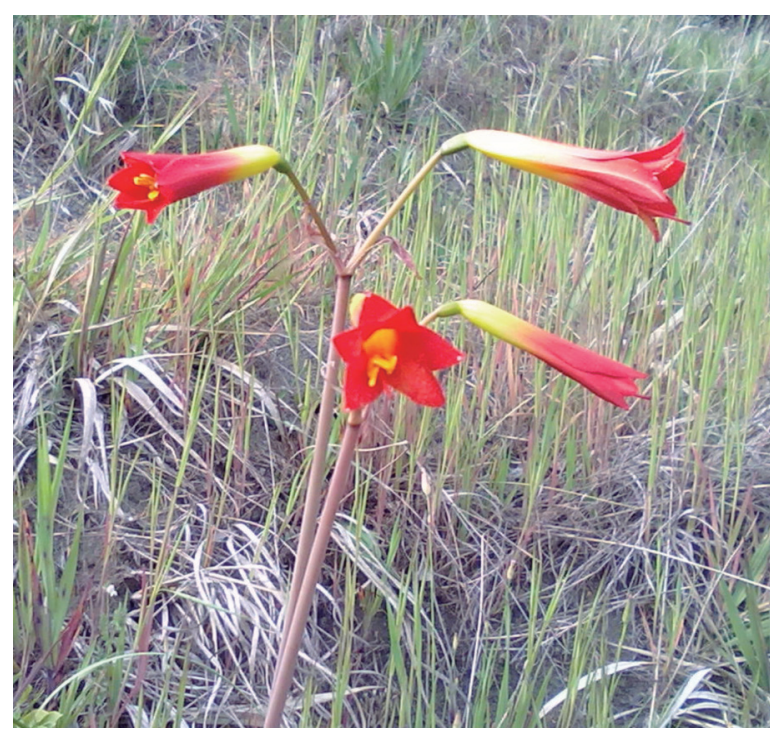

Figure 1. Photograph of Phycella australis taken in the field.

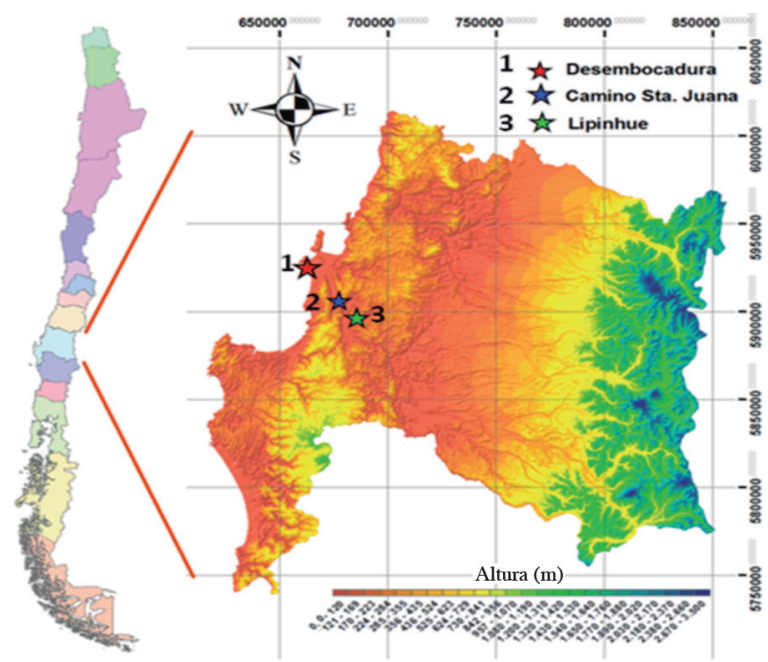

Figure 2. Reference map of the studied populations: 1) Desembocadura, 2) Santa Juana, and 3) Lipinhue.

isopropanol al $-20{ }^{\circ} \mathrm{C}$ for $1 \mathrm{~h}$. The DNA was pelleted down by centrifugation at $14000 \mathrm{rpm}$ for $10 \mathrm{~min}$ and then was suspended in Ultra Pure water. The concentration was estimated through spectrophotometry (Picodrop, Hinxton, UK) and visualized in agarose gel electrophoresis.

\section{ISSR amplification}

Six ISSR primers (Table 1) previously tested in Rhodophiala Presl. and Lycoris longituba (Deng et al., 2006b; Fuentes et al., 2007) were used. The amplification was performed in a $50 \mu \mathrm{L}$ reaction volume containing $200 \mathrm{ng}$ of genomic DNA, $0.5 \mu \mathrm{L}$ of Tag polymerase (Promega ${ }^{\circledR}$ ), $0.2 \mu \mathrm{M}$ of each primer, $0.25 \mathrm{mM}$ of each $\mathrm{dNTP}$ and $3 \mathrm{mM} \mathrm{MgCl}_{2}$. Initial denaturation was $3 \mathrm{~min}$ at $94{ }^{\circ} \mathrm{C}$, followed by 38 cycles of $30 \mathrm{~s}$ at $94{ }^{\circ} \mathrm{C}, 30 \mathrm{~s}$ at $50{ }^{\circ} \mathrm{C}, 90 \mathrm{~s}$ at $72{ }^{\circ} \mathrm{C}$. An additional cycle of $7 \mathrm{~min}$ 
at $72{ }^{\circ} \mathrm{C}$ was used for primer extension; the polymerase chain reaction (PCR) was performed in a thermal cycler (Swift maxi, ESCO, Singapore).

The PCR products were analyzed on $2 \%$ agarose gels and stained with $2 \mu \mathrm{L}$ GelRed (Biotium, Hayward, California, USA) photographed under ultraviolet light by using gel documentation system. Molecular weight was estimated by using $1 \mathrm{~kb}$ DNA Ladder (Promega, Madison, Wisconsin, USA).

\section{Data analysis}

According to band patterns, a binary matrix was constructed by assigning a binary number to each DNA sample: 1 for presence of the band; 0 for absence. This matrix was analyzed using GenAlEx version 6.41 software (Peakall and Smouse, 2006). The number of polymorphic loci, percentage of polymorphic loci, Shannon diversity index (I) (Shannon and Weaver, 1949), expected heterozygosity (He) and degree of population differentiation $\left(\mathrm{G}_{\mathrm{st}}\right)$ (Nei, 1978) were calculated to estimate genetic diversity on these three $P$. australis populations. Besides, a Nei (1978) genetic distances dendrogram was constructed using the UPGMA method (Sneath and Sokal, 1973) through the POPGENE software (Yeh et al., 1997). Finally an analysis of molecular variance (AMOVA) was performed using GenA1Ex software (Excoffier, 1993). To verify the relation between the genetic distance and geographic distance a correlation analysis was performed using a Mantel Test (Mantel, 1967).

\section{RESULTS AND DISCUSSION}

According to the results it is possible to state that selected primers were adequate to detect genetic diversity on this species. The six ISSR primers chosen were able to amplify 51 fragments (Table 1); an average of 8.5 bands was obtained per primer. In this study, a higher number of band per primers were obtained, in relation to another Amaryllidaceae species Lycoris longituba (Deng et al., 2006a) where only 7.5 bands per primer were found. This indicates, that $P$. australis has a genome with more complementary zones for primers used than P. longituba. Furthermore, this can be compared with other ISSR primers used in Tigridia pavonia (L.f.) Redouté (Piña et al., 2010) and Phaseolus vulgaris L. (Galván et al., 2003) where average 4.2 and 8 bands were obtained, respectively.

Table 1. ISSR primers selected and the average number of bands (Nb) by a primer in Phycella australis in the province of Concepción.

\begin{tabular}{llc}
\hline Primer & \multicolumn{1}{c}{ Primer sequence } & $\mathrm{Nb}$ \\
\hline ISSR-03 & 5'ACACACACACACACACTT 3' & 7 \\
ISSR-04 & 5'ACACACACACACACACAG 3' & 9 \\
ISSR-23 & 5'ACACACACACACACACTA 3' & 8 \\
ISSR-44 & 5'ACACACACACACACACGA 3' & 9 \\
ISSR-47 & 5'ACACACACACACACACGT 3' & 9 \\
ISSR-59 & 5'AGAGAGAGAGAGAGAGGC 3' & 9 \\
& Total & 51 \\
& Rates & 8.5 \\
\hline
\end{tabular}

The genetic variability rates obtained from the binary matrix are available on Table 2. These three populations showed an average of 37 polymorphic loci corresponding to $72.55 \%$. The polymorphism percentage detected in $P$. australis is within the range previously founded for other Amaryllidaceae species such as Narcissus poeticus L. and $N$. radiiflorus Salisb. (88\%, Tucci et al., 2004) and in $L$. longituba (65.96\%, Deng et al., 2006b), despite of the fact that this studies have been performed with others types of molecular markers (AFLP and RAPD, respectively).

Hamrick and Godt (1996) agree that plants with different reproductive methods, seed dispersion mechanisms, geographic distribution, and life forms tend to maintain different levels of genetic variability within populations. According to the values of genetic variability from Nybom (2004) using RAPD, P. australis has a within population variability (He: 0.239$)$ that agrees with other endemic species (He: 0.20), with an expected heterozygosity of He: 0.239 in average.

Besides, according to the AMOVA genetic variability of the species is explained by within population variation with an $83 \%(\mathrm{p}<0.01)$ (Table 3$)$. According to the results, genetic variability is higher within populations, and this percentage is quite similar to that obtained in L. longituba, with $71.75 \%$ variation within studied populations (Deng et al., 2006b).

The Nei's average genetic identity (Nei, 1973) was obtained (Gst: 0.171), with a value very similar to the ones reported by Nybom (2004) for endemic species (Gst: 0.18 ). The genetic similarity relatedness between the three populations in the dendrogram of Nei's genetic identities (Figure 3) showed greater genetic identity between Santa Juana and Lipinhue populations. This correlation agrees which Parab and Krishnan (2008), indicating that geographic distances often explain genetic similarities.

Mantel test indicated that there is strong correlation between geographic and genetic distance (R: 0.620;

Table 2. Analyzed genetic diversity rates in three populations of Phycella australis in the province of Concepción based on intersimple sequence repeat (ISSR).

\begin{tabular}{lcccc}
\hline Population & LP & $\mathrm{P}(\%)$ & $\mathrm{I}$ & $\mathrm{He}$ \\
\hline Desembocadura & 36 & 70.59 & 0.4132 & 0.219 \\
Santa Juana & 39 & 76.47 & 0.4407 & 0.280 \\
Lipinhue & 36 & 70.59 & 0.3916 & 0.220 \\
Average & 37 & 72.55 & - & 0.239 \\
\hline
\end{tabular}

LP: numbers polymorphic loci; P: percentage of polymorphic loci; I: Shannon rate; He: expected heterozygosity.

Table 3. Analysis of molecular variance (AMOVA) among and within populations of Phycella australis based on ISSR in the province of Concepción.

\begin{tabular}{lrrrrc}
\hline Variability source & gl & \multicolumn{1}{c}{ SC } & CM & CV & V (\%) \\
\hline Among populations & 2 & 53.667 & 26.833 & 1.581 & 17 \\
Within populations & 33 & 259.417 & 7.861 & 7.861 & 83 \\
Total & 35 & 313.083 & - & 9.442 &
\end{tabular}

gl: degrees of freedom; SC: sum of squares; CM: mean squares, CV: coefficient of variance; V: percentage of variance with $\mathrm{p}<0.01$ level of significance. 
P: 0.496) (Table 4). According to results, Santa Juana and Lipinhue are generically similar, indicating lower differences between them. But, among these two populations, Lipinhue is the one that is more genetically similar to Desembocadura.

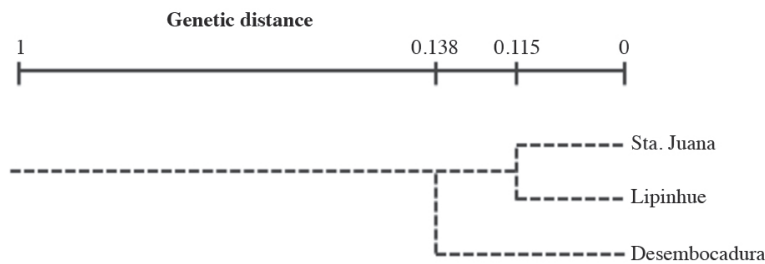

Figure 3. Dendrogram (unweighted pair group method with arithmetic mean, UPGMA) based on Nei's genetic distance matrix for three populations of Phycella australis analyzed.

Table 4. Nei's genetic identity (above diagonal) and genetic distance (below diagonal) in three populations of Phycella australis in the province of Concepción.

\begin{tabular}{lccr}
\hline Population & Desembocadura & Santa Juana & Lipinhue \\
\hline Desembocadura & - & 0.8587 & 0.8834 \\
Santa Juana & 0.1523 & - & 0.8914 \\
Lipinhue & 0.1240 & 0.1150 & - \\
\hline
\end{tabular}

\section{CONCLUSIONS}

From the conservation perspective for this species, the results indicate that the genetic variability is enough to ensure the maintenance of the natural populations, probably due to commercial extraction is incipient yet. The genetic variability between populations indicates that genetic flow exists among studied populations. This result is important to ensure a proper genetic variability for maintenance of the species considering the actual climate change scenario. Due to the economic potential value of $P$. australis as ornamental plant, is important to consider these genetic results for the development of conservation strategies.

\section{ACKNOWLEDGEMENTS}

The authors would like to thanks to Dr. Carlos Baeza for his support during plant material sampling, and encourage this research.

\section{LITERATURE CITED}

Arnao, E., Y. Jayaro, P. Hinrichsen, C. Ramis, R.C. Marín, y I. Pérez-Almeida. 2008. Marcadores AFLP en la evaluación de la diversidad genética de variedades y líneas élites de arroz en Venezuela. Interciencia 33:359-364.

Arroyo-Leuenberger, S., y J. Dutilh. 2008. Amaryllidaceae. 203-226. In Zuloaga, F., O. Morrone, y M. Belgrano (eds.) Catálogo de las plantas vasculares del Cono Sur. Missouri Botanical Garden, Saint Louis, Missouri, USA.

Baeza, C.M., E. Ruiz, y M. Negritto. 2007a. El número cromosómico de Phycella australis Ravenna (Amaryllidaceae). Gayana Botánica 64:119-122.
Baeza, C.M., O. Schrader, A. Terrab, T. Stuessy, M. Rosas, E. Ruiz, et al. 2007b. Chromosomes report from plants are growing in Chile. III. Gayana Botánica 64:175-183.

Deng, C-L., D., J. Zhou, L-D. Lu, W-J. Gao, S-F. Li, and Q. Wang. 2006a. Study on germplasm resources of Lycoris longituba (Amarylliadaceae) using RAPD and ISSR. Acta Botanica Yunnanica 28:300-304.

Deng, C-L., J. Zhou, W-J. Gao, F-C. Sun, R-Y Qin, and L-D. Lu. 2006b. Assessment of genetic diversity of Lycoris longituba (Amaryllidaceae) detected by RAPDs. Journal of Genetics 85:205-207.

Doyle, J.J., and J.L. Doyle. 1987. A rapid DNA isolation procedure for small quantities of fresh leaf tissue. Phytochemistry Bulletin 19:11-15.

Excoffier, L. 1993. Analysis of molecular variance (AMOVA), version 1.55. Genetics and Biometry Laboratory, University of Geneva, Switzerland.

Fuentes, L., F. Shiappacasse, R. Herrera, P. Peñailillo, y H. Vogel. 2007. Evaluación preliminar de las relaciones interespecíficas en Rhodophiala Presl. (Amaryllidaceae) mediante marcadores moleculares ISSR. Agro Sur 35:47-49.

Galván, M.Z., B. Bornet, P.A. Balatti, and M. Branchard. 2003. Inter simple sequence repeat (ISSR) markers as a tool for the assessment of both genetic diversity and gene pool origin in common bean (Phaseolus vulgaris L.) Euphytica 132:297-301.

Hamrick, J.L., and M.J.W. Godt. 1996. Effects of life history traits on genetic diversity in plant species. Philosophical Transactions of the Royal Society B, Biological Sciences 351:1291-1298.

Jiménez, P., y C. Collada. 2000. Técnicas para la evaluación de la diversidad genética y su uso en los programas de conservación. Investigación Agraria. Sistemas y Recursos Forestales 2:237-248.

Lande, R., and S. Shannon. 1996. The role of genetic variation in adaptation and population persistance in changing environment Evolution 50:434-437

Lara, A., R. Valdeverde, O. Rocha, y L. Gómez. 2003. Variabilidad y diferenciación genética en cuatro poblaciones de la planta medicinal Psychotria acuminata en Costa Rica. Agronomía Costarricense 27:29-42.

Lynch, M. 1996. A quantitative genetic perspective on conservation issues. p. 471-501. In Avise, J.C., and J.L. Hamrick (eds.) Conservation genetics. Case histories from nature. Chapman \& Hall, New York, USA.

Mantel,N. 1967. The detection of disease clustering and a generalized regression approach. Cancer Research UK 27:209-220.

Muñoz, M., R. Riegel, P. Seemann, P. Peñailillo, F. Schiappacasse, y J Nuñez. 2011. Relaciones filogenéticas de Rhodolirium montanum Phil. y especies afines, basadas en secuencias nucleotídicas de la región ITS y análisis cariotípico. Gayana Botánica 68:40-48.

Nei, M. 1973. Analysis of gene diversity in subdivided populations Proceedings of the National Academy of Sciences 70:3321-3323.

Nei, M. 1978. Estimation of average heterozygosity and genetic distance from a small number of individuals. Genetics 89:583-590.

Nybom, H. 2004. Comparison of different nuclear DNA markers for estimating intraspecific genetic diversity in plants. Molecular Ecology 13:1143-1155.

Parab, G.V., and S. Krishnan. 2008. Assessment of genetic variation among populations of Rhynchostylis retusa, an epiphytic orchid from Goa, India using ISSR and RAPD markers. Indian Journal Biotechnology 7:313-319.

Peakall, R., and P.E. Smouse. 2006. GENALEX6: genetic analysis in Excel. Population genetic software for teaching and research. Molecular Ecology Notes 6:288-295.

Piña, J., L. Vázquez, and A. Arzate. 2010. In vitro regeneration and genetic fidelity of Tigridia pavonia (L.f.) Redouté. Electronic Journal of Biotechnology 13:7-8.

Reyes, M., y D. Barrera. 2009. Las flores de corte chilenas en 2007 y 2008. Publicación de la Oficina de Estudios y Políticas Agrarias (ODEPA), Ministerio de Agricultura, Santiago, Chile.

Schiappacasse, F., P. Peñailillo, P. Yáñez, and M. Bridgen. 2005 Propagation studies on Chilean geophytes. Acta Horticulturae 673:121-126 
Semagn, K., A. Bjornstad, and M.N. Ndjiondjop. 2006. An overview of molecular marker methods for plants. African Journal of Biotechnology 5:2540-2568.

Shannon, C.E., and W. Weaver. 1949. The mathematical theory of communication. 125 p. University of Illinois Press, Urbana, Illinois, USA

Sneath, P.H.A., and R.R. Sokal. 1973. Numerical taxonomy: the principles and practices of numerical classification. 623 p. W.H. Freeman Company, San Francisco, California, USA.
Tucci, G.F., M.O. Winfield, G.F. D’Amato, C. Gregori, B. Trombetta, and R.I. De Dominicis. 2004. Genetic diversity in Narcissus poeticus L. and $N$. radiiflorus Salisb. (Amaryllidaceae) in two different populations: AFLP and karyological studies. Caryologia 57:405-411.

Yeh, F.C., R.C. Yang, T.B.J. Boyle, Z.H. Ye, and J.X. Mao. 1997. POPGENE, the user-friendly shareware for population genetic analysis. Molecular Biology and Biotechnology Centre, University of Alberta, Edmonton, Canada. 